University of Nebraska - Lincoln

DigitalCommons@University of Nebraska - Lincoln

Biological Systems Engineering: Papers and

Publications

Biological Systems Engineering

8-1991

\title{
Roughness Coefficients for Selected Residue Materials
}

John E. Gilley

University of Nebraska-Lincoln, john.gilley@ars.usda.gov

Eugene R. Kottwitz

University of Nebraska-Lincoln

Gary A. Wieman

University of Nebraska-Lincoln

Follow this and additional works at: https://digitalcommons.unl.edu/biosysengfacpub

Part of the Biological Engineering Commons

Gilley, John E.; Kottwitz, Eugene R.; and Wieman, Gary A., "Roughness Coefficients for Selected Residue Materials" (1991). Biological Systems Engineering: Papers and Publications. 76.

https://digitalcommons.unl.edu/biosysengfacpub/76

This Article is brought to you for free and open access by the Biological Systems Engineering at DigitalCommons@University of Nebraska - Lincoln. It has been accepted for inclusion in Biological Systems Engineering: Papers and Publications by an authorized administrator of DigitalCommons@University of Nebraska Lincoln. 


\title{
ROUGHNESS COEFTICIENTS FOR SELECTED Residue Materials
}

\author{
By John E. Gilley, ${ }^{1}$ Eugene R. Kottwitz, ${ }^{2}$ and Gary A. Wieman ${ }^{3}$
}

\begin{abstract}
ABstact: Analysis of surface runoff on upland areas requires identification of roughness coefficients. A laboratory study is conducted to measure Darcy-Weisbach and Manning roughness coefficients for corn, cotton, peanut, pine needles, sorghum, soybeans, sunflower, and wheat residue. Varying rates of flow are introduced into a flume in which selected amounts of residue are securely attached. Roughness coefficients are calculated from measurements of discharge rate and flow velocity. The laboratory data are used to derive regression equations for relating roughness coefficients to Reynolds number and either percent residue cover or residue rate. Separate equations are developed for Reynolds number values from 500 to 20,000 , and from 20,000 to 110,000 . Generalized equations are presented for estimating roughness coefficients for other residue materials not used in this investigation. Accurate prediction of roughness coefficients for residue materials will improve our ability to understand and properly model upland flow hydraulics.
\end{abstract}

\section{INTRODUCTION}

Analysis of surface runoff on upland areas requires identification of hydraulic roughness coefficients. Roughness coefficients are used in the calculation of flow velocity and the routing of runoff hydrographs. The ability to understand and properly model upland flow hydraulics is also essential in the development of process-based erosion models.

On agricultural areas, resistance to flow may be caused by frictional drag over the soil surface, standing vegetative material, residue cover and rocks lying on the surface, raindrop impact, and other factors. Each of these elements may contribute to total hydraulic resistance. Conservation tillage systems have been developed that rely heavily on surface crop residues as a primary means of controlling runoff and soil erosion.

The effects of raindrop impact on flow resistance over a smooth surface were examined by Shen and $\mathrm{Li}$ (1973). A set of regression equations were presented to describe variations in Darcy-Weisbach friction factors with rainfall intensity and Reynolds number. Gilley et al. (1990) measured hydraulic characteristics of rills at 11 sites located throughout the eastern United States. Regression equations were developed that related Darcy-Weisbach and Manning roughness coefficients to Reynolds number.

A comprehensive description of previous studies involving roughness coefficients on agricultural and natural areas was provided by Engman (1986). Hydraulic roughness coefficients were developed from runoff plot data originally collected for erosion studies. Friction factors were presented in a tabular format with a description of various surfaces and land uses.

\footnotetext{
${ }^{1}$ Agric. Engr., USDA-ARS, Univ. of Nebraska, Lincoln, NE 68583-0729. NE.

${ }^{2}$ Res. Engr., Dept. of Biological Systems Engrg., Univ, of Nebraska, Lincoln, NE.

${ }^{3}$ Res. Engr., Dept. of Biological Systems Engrg., Univ. of Nebraska, Lincoln,

Note. Discussion open until January 1, 1992. To extend the closing date one month, a written request must be filed with the ASCE Manager of Journals. The manuscript for this paper was submitted for review and possible publication on August 9, 1990. This paper is part of the Journal of Irrigation and Drainage Engineering, Vol. 117, No. 4, July/August, 1991. CASCE, ISSN 0733-9437/91/0004-0503/\$1.00+ $\$ .15$ per page. Paper No. 26068.
} 
Liong et al. (1989) developed a simple method for assigning Manning roughness coefficients to overland flow segments in kinematic wave models. The proposed method was found to work well on a gaged basin. This procedure may be useful in estimating hydrographs for ungaged watersheds.

Laboratory measurements of roughness coefficients on surfaces covered with sand or gravel were conducted by Woo and Brater (1961), Emmett (1970), Phelps (1975), and Savat (1980). Similar tests were performed under field conditions on natural landscapes by Dunne and Dietrich (1980), Roels (1984), and Abrahams et al. (1986). In most of these studies, roughness coefficients decreased with increasing Reynolds number. Once roughness elements are submerged, their ability to retard overland flow is reduced as the depth of overland flow becomes greater. A similar reduction in roughness coefficients with increasing Reynolds number would be expected for residue materials.

The quantity of crop material found on the soil surface is usually greatest following harvest. After harvest, residue material is subjected to decomposition. Tillage serves to incorporate the residue material into the soil and thus reduces surface cover. Procedures are available for estimating the reduction in surface cover caused by tillage (Colvin et al. 1986).

Crop residues found on the soil surface are usually identified on a percentcover or residue-rate basis. Surface cover can be rapidly and accurately measured in the field. Crop growth models typically provide estimates of vegetative dry matter production. Residue rate may also be measured by removing and drying the vegetative material collected from a representative area.

The objective of this investigation was to develop regression equations for estimating roughness coefficients for selected residue materials. Relationships are identified for predicting both Darcy-Weisbach and Manning roughness coefficients. These equations use Reynolds number and either percent cover or residue rate as independent variables.

\section{Hydraulic Equations}

The Darcy-Weisbach and Manning equations have been widely used to describe flow characteristics. Both of these relations contain a roughness coefficient. Under uniform flow conditions, the Darcy-Weisbach roughness coefficient, $f$, is given as (Chow 1959)

$f=\frac{8 \mathrm{~g} R S}{V^{2}}$.

where $\mathrm{g}=$ acceleration due to gravity; $S=$ average slope; $V=$ flow velocity; and hydraulic radius, $R$, is defined as

$R=\frac{A}{P}$

where $A=$ cross-sectional flow area; and $P=$ wetted perimeter. For a rectangular flume with flow width $b$

$R=\frac{b y}{b+2 y}$ 
where $y=$ flow depth. For overland flow conditions where flow width is much greater than flow depth; hydraulic radius can be assumed to be approximately equal to flow depth.

The Manning roughness coefficient, $n$, is given as

$n=\frac{R^{2 / 3} S^{1 / 2}}{V}$

Manning and Darcy-Weisbach roughness coefficients can be related using the following equation

$n=\left[f \frac{R^{1 / 3}}{8 \mathrm{~g}}\right]^{1 / 2}$

Reynolds number is also used to describe flow characteristics. Reynolds number, $R$, is given as

$\mathrm{R}=\frac{V R}{y}$

where $v=$ kinematic viscosity, which can be determined directly from water temperature.

The continuity equation for flow is defined as

$Q=V A$

where $Q=$ flow rate. For a rectangular flume, water depth is given as

$y=\frac{Q}{V b}$

In this study, water depth was determined indirectly using (8), and measurements of $Q, V$, and $b$.

\section{Experimental Procedures}

The types of residue used in this study included corn, cotton, peanut, pine needles, sorghum, soybeans, sunflower, and wheat. Needles produced by ponderosa pine were included to obtain an estimate of roughness coefficients on forested areas. After the residue materials had been removed from the field, they were placed in an oven and dried. For each residue type, 10 separate residue elements were selected for measurement of residue dimensions. Mean residue diameter and length are shown in Table 1.

A measured mass of residue material was glued in a random orientation onto a section of reinforced fiberglass sheeting. For each residue type, five residue rates were selected. All of the residue materials except pine needles and wheat were applied at rates equivalent to $2,4,6,8$, and 10 metric tons/ ha. Rates equivalent to $0.75,2,4,6$, and 8 metric tons/ha were used for pine needles, while wheat straw was applied at rates equivalent to 0.25 , $0.50,1,2$, and 4 metric tons/ha. Since pine needle and wheat residue elements had smaller diameters than the other residue materials, they furnished greater surface cover at a given residue rate.

The percentage of surface cover provided at a given residue rate was ob- 
TABLE 1. Diameter, Length, Residue Rate, and Surface Cover of Vegetative Materials

\begin{tabular}{l|c|c|c|c}
\hline $\begin{array}{c}\text { Residue } \\
\text { type } \\
(1)\end{array}$ & $\begin{array}{c}\text { Diameter } \\
(\mathrm{cm}) \\
(2)\end{array}$ & $\begin{array}{c}\text { Length } \\
(\mathrm{cm}) \\
(3)\end{array}$ & $\begin{array}{c}\text { Residue rate } \\
\text { (metric tons/ha) } \\
(4)\end{array}$ & $\begin{array}{c}\text { Surface } \\
\text { cover }(\%) \\
(5)\end{array}$ \\
\hline Corn & 1.87 & 42.9 & $2-10$ & $25-81$ \\
Cotton & 0.73 & 36.2 & $2-10$ & $12-50$ \\
Peanut & 0.36 & 20.2 & $2-10$ & $17-84$ \\
Pine needles & 0.12 & 12.6 & $0.75-8$ & $30-93$ \\
Sorghum & 1.59 & 35.7 & $2-10$ & $22-91$ \\
Soybeans & 0.40 & 13.1 & $2-10$ & $32-93$ \\
Sunflower & 1.93 & 42.2 & $2-10$ & $15-63$ \\
Wheat & 0.30 & 19.4 & $0.25-4$ & $26-99$ \\
\hline
\end{tabular}

tained using a photographic grid procedure (Laflen et al. 1978). Residue covers on the fiberglass sheets were photographed using $35-\mathrm{mm}$ color slide film. The slides were projected onto a screen on which a grid had been superimposed. The number of grid intersections over residue material was determined visually from the projected slides and surface cover was then calculated. For each residue rate, six measurements of surface cover were obtained. The range in surface cover values for each residue type is shown in Table 1.

The fiberglass sheets with the attached residue were placed in a flume $0.91-\mathrm{m}$ wide, $7.31-\mathrm{m}$ long, and $0.279-\mathrm{m}$ deep. The slope gradient of the flume was maintained at $1.35 \%$. Water was supplied to the flume using a constant head tank. Two replicated tests were run at 15 flow rates ranging from $5.24 \times 10^{-4}$ to $1.01 \times 10^{-1} \mathrm{~m}^{3} / \mathrm{s}$. Flow rate was determined immediately before and after each test to ensure steady state conditions. Water temperature was measured following flow rate determinations.

Reynolds number values varied from approximately 500 to 110,000 . It was difficult to maintain uniform flow conditions on the residue covered surfaces for Reynolds numbers less than approximately 500. The flow capacity of the flume would have been exceeded for Reynolds number values significantly greater than 110,000 .

Once steady state runoff conditions had become established, line sources of fluorescent dye were injected across the flume at downslope distances of $0.91 \mathrm{~m}$ and $7.01 \mathrm{~m}$. A fluorometer was used to determine time of travel of the dye concentration peaks. Mean flow velocity was identified by dividing the distance between the two line sources of dye $(6.10 \mathrm{~m})$ by the difference in travel time between the two dye concentration peaks. Peak concentration was used because the dye concentration-time curves were symmetric. For each test sequence, three measurements of flow velocity were made.

Roughness coefficients for the fiberglass sheets on which the residue materials were placed were also identified. The experimental procedures used to measure roughness coefficients for the fiberglass sheets with and without residue were identical. Roughness coefficients induced by the bare fiberglass sheets at a given Reynolds number were subtracted from measurements obtained with attached residue to determine hydraulic resistance caused by the residue materials alone. 


\section{Pesulte and Analysis}

Surface-cover-residue-rate relationships obtained using regression analysis are given herein. Equations for estimating Darcy-Weisbach and Manning roughness coefficients for the residue materials are also provided. Finally, procedures for predicting roughness coefficients for residue materials not included in this study are presented.

\section{Surface Cover-Residue Rate Conversion}

Both surface cover and residue rate are used to characterize the amount of vegetative material found on the soil surface. It may sometimes be necessary to make conversions between surface cover and residue rate for a particular vegetative material. Regression equations for making these conversions are shown in Table 2 .

Surface cover and residue rate values used to derive the regression equations are presented in Table 1 . The range in surface cover and residue rate values varied considerably between residue materials. The regression relationships shown in Table 2 should not be used for values of surface cover or residue rate outside of the range for which they were derived.

\section{Darcy-Weisbach Roughness Coefficients}

Darcy-Weisbach roughness coefficients at varying Reynolds numbers for selected rates of wheat residue are shown in Fig. 1. The trends presented in Fig. 1 are characteristic not only of wheat residue but also the other vegetative materials used in this investigation. It can be seen in Fig. 1 that for a given residue rate, the Darcy-Weisbach friction factor consistently decreased as Reynolds number increased for Reynolds numbers less than approximately 20,000 . Other investigators have obtained similar results for sandcovered surfaces.

The variation in Darcy-Weisbach roughness coefficient with Reynolds number was much less pronounced for Reynolds numbers greater than 20,000. Surface cover values of approximately $70 \%, 79 \%$, and $99 \%$ were provided by wheat residue at rates of 1,2 , and 4 metric tons/ha, respectively. These three wheat residue rates produced similar roughness coefficients for Reynolds numbers greater than 20,000 .

\section{TABLE 2. Regression Equations for Surface Cover versus Residue Rate}

\begin{tabular}{l|c|c}
\hline \hline $\begin{array}{c}\text { Residue type } \\
(1)\end{array}$ & $\begin{array}{c}\text { Regression coefficient, }{ }^{a} a \\
(2)\end{array}$ & $\begin{array}{c}\text { Coefficient of determination, } r^{2} \\
(3)\end{array}$ \\
\hline Corn & 0.155 & 0.978 \\
Cotton & 0.0676 & 0.984 \\
Peanut & 0.180 & 0.979 \\
Pine needles & 0.370 & 0.978 \\
Sorghum & 0.184 & 0.920 \\
Soybeans & 0.243 & 0.963 \\
Sunflower & 0.102 & 0.986 \\
Wheat & 1.10 & 0.997 \\
\hline
\end{tabular}

${ }^{a}$ Regression coefficient $a$ is used in equation: surface cover $=100\left(1-e^{-a \text { residue rate }}\right)$, where surface cover is given as percentage and residue rate is in metric tons per hectare. 


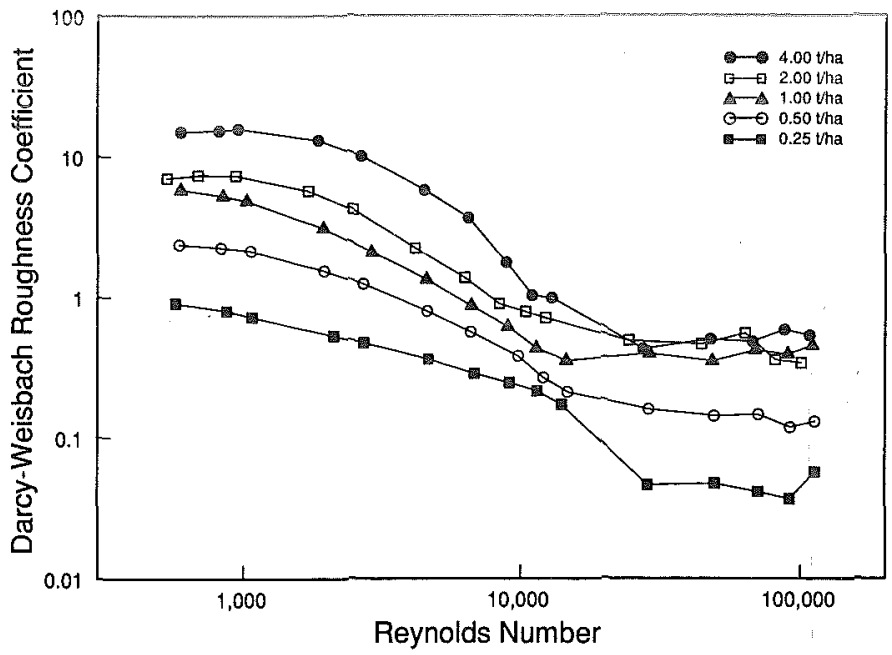

FIG. 1. Darcy-Weisbach Roughness Coefficients as Function of Reynolds Number for Selected Rates of Wheat Residue

When developing regression relationships for the data presented in Fig. 1, separate equations were derived for Reynolds numbers less than and greater than 20,000. Regression equations for Darcy-Weisbach roughness coefficient versus percent cover and Reynolds number are presented in Tables 3 and 4 for Reynolds numbers less than and greater than 20,000, respectively. For Reynolds numbers less than 20,000 (Table 3), a generalized equation was computed using data from all of the residue types.

Regression equations for Darcy-Weisbach roughness coefficient versus

TABLE 3. Regression Equations for Darcy-Weisbach Roughness Coefficient versus Percent Cover and Reynolds Number for Reynolds Number Less than 20,000

\begin{tabular}{|c|c|c|c|c|}
\hline \multirow[b]{2}{*}{$\begin{array}{c}\text { Residue type } \\
\text { (1) }\end{array}$} & \multicolumn{3}{|c|}{ Regression Coefficients ${ }^{a}$} & \multirow{2}{*}{$\begin{array}{c}\text { Coefficient of } \\
\text { determination, } r^{2} \\
(5)\end{array}$} \\
\hline & $\begin{array}{c}a \\
(2)\end{array}$ & $\begin{array}{c}b \\
(3)\end{array}$ & $\begin{array}{c}c \\
(4)\end{array}$ & \\
\hline Corn & $6.30 \times 10^{-2}$ & 1.53 & $2.34 \times 10^{-1}$ & 0.911 \\
\hline Cotton & $8.88 \times 10^{-2}$ & 1.02 & $7.88 \times 10^{-2}$ & 0.731 \\
\hline Peanut & $2.61 \times 10^{-1}$ & 1.56 & $5.06 \times 10^{-1}$ & 0.924 \\
\hline Pine needles & $8.71 \times 10^{-5}$ & 3.63 & $6.52 \times 10^{-1}$ & 0.874 \\
\hline Sorghum & 5.24 & $7.96 \times 10^{-1}$ & $4.55 \times 10^{-1}$ & 0.960 \\
\hline Soybeans & $9.28 \times 10^{-2}$ & 2.84 & 1.02 & 0.919 \\
\hline Sunflower & 1.66 & $8.87 \times 10^{-1}$ & $3.51 \times 10^{-1}$ & 0.916 \\
\hline Wheat & $2.98 \times 10^{-4}$ & 3.27 & $6.28 \times 10^{-1}$ & 0.938 \\
\hline All residue types & & & & \\
\hline combined & $1.27 \times 10^{-1}$ & 1.55 & $3.88 \times 10^{-1}$ & 0.648 \\
\hline
\end{tabular}

${ }^{\mathrm{a}}$ Regression coefficients $a, b$, and $c$ used in equation: $f=a$ (percent cover) ${ }^{\mathrm{b}} /$ (Reynolds number) ${ }^{c}$. 
TABLE 4. AGgression Equations for Darcy Waisbach Roughnse Cosficlent versus Percent Cover and Reynolds Number for Reynolds Number Greater than 20,000

\begin{tabular}{|c|c|c|c|c|}
\hline \multirow{2}{*}{$\begin{array}{c}\text { Residue } \\
\text { type } \\
\text { (1) }\end{array}$} & \multicolumn{3}{|c|}{ Regression Coefficients ${ }^{a}$} & \multirow{2}{*}{$\begin{array}{l}\text { Coefficient of } \\
\text { determination, } r^{2} \\
(5)\end{array}$} \\
\hline & $\begin{array}{c}a \\
(2)\end{array}$ & $\begin{array}{c}b \\
\text { (3) }\end{array}$ & $\begin{array}{c}c \\
(4)\end{array}$ & \\
\hline Corn & $1.23 \times 10^{-2}$ & 2.97 & $6.82 \times 10^{-1}$ & 0.953 \\
\hline Cotton & $3.84 \times 10^{-2}$ & 1.35 & $1.44 \times 10^{-1}$ & 0.878 \\
\hline Peanut & $5.75 \times 10^{-2}$ & $7.80 \times 10^{-1}$ & $5.44 \times 10^{-2}$ & 0.899 \\
\hline Pine needles & $1.83 \times 10^{-4}$ & 2.47 & $2.32 \times 10^{-1}$ & 0.877 \\
\hline Sorghum & $1.44 \times 10^{-1}$ & 1.73 & $5.31 \times 10^{-1}$ & 0.804 \\
\hline Soybeans & $3.20 \times 10^{-3}$ & 2.13 & $3.88 \times 10^{-1}$ & 0.828 \\
\hline Sunflower & $1.18 \times 10^{-1}$ & 1.82 & $4.63 \times 10^{-1}$ & 0.782 \\
\hline Wheat & $4.26 \times 10^{-4}$ & 1.92 & $1.45 \times 10^{-1}$ & 0.855 \\
\hline
\end{tabular}

${ }^{a}$ Regression coefficients $a, b$, and $c$ used in equation: $f=a$ (Percent cover $)^{b} /($ Reynolds number) ${ }^{c}$,

residue rate and Reynolds number are reported in Tables 5 and 6 for Reynolds numbers less than and greater than 20,000, respectively. Measurements obtained from the various residue materials were combined (Table 6) to develop a generalized equation for use with values of Reynolds number greater than 20,000. In the generalized equation, the Darcy-Weisbach roughness coefficient can be seen to vary with residue rate in a nearly linear fashion.

\section{Manning Roughness Coefficients}

Fig. 2 presents Manning roughness coefficients as a function of Reynolds number for selected rates of wheat residue. As required by (5), the shapes of the curves shown in Figs. 1 and 2 are very similar. The characteristic reduction in roughness coefficient with increasing Reynolds number for Reynolds number values less than 20,000 is evident in Fig. 2.

TABLE 5. Regression Equations for Darcy-Weisbach Roughness Coefficient versus Residue Rate and Reynolds Number for Reynolds Number Less than 20,000

\begin{tabular}{|c|c|c|c|c|}
\hline \multirow{2}{*}{$\begin{array}{c}\text { Residue } \\
\text { type } \\
(1)\end{array}$} & \multicolumn{3}{|c|}{ Regression Coefficients $^{a}$} & \multirow{2}{*}{$\begin{array}{c}\text { Coefficient of } \\
\text { determination, } r^{2} \\
(5)\end{array}$} \\
\hline & $\begin{array}{c}a \\
(2)\end{array}$ & $\begin{array}{c}b \\
(3)\end{array}$ & $\begin{array}{c}c \\
(4)\end{array}$ & \\
\hline Corn & $4.60 \times 10^{-1}$ & 1.65 & $1.09 \times 10^{-1}$ & 0.774 \\
\hline Cotton & $5.73 \times 10^{-1}$ & $9.30 \times 10^{-1}$ & $7.89 \times 10^{-2}$ & 0.751 \\
\hline Peanut & $1.01 \times 10^{+1}$ & 1.33 & $4.72 \times 10^{-1}$ & 0.933 \\
\hline Pine needles & $7.87 \times 10^{+1}$ & 1.58 & $7.10 \times 10^{-1}$ & 0.917 \\
\hline Sorghum & $7.07 \times 10^{+1}$ & $7.69 \times 10^{-1}$ & $5.60 \times 10^{-1}$ & 0.929 \\
\hline Soybeans & $6.06 \times 10^{+2}$ & 1.81 & 1.04 & 0.917 \\
\hline Sunflower & $1.43 \times 10^{+1}$ & $7.39 \times 10^{-1}$ & $3.72 \times 10^{-1}$ & 0.903 \\
\hline Wheat & $3.71 \times 10^{+2}$ & $9.91 \times 10^{-1}$ & $6.80 \times 10^{-1}$ & 0.937 \\
\hline
\end{tabular}

${ }^{a}$ Regression coefficients $a, b$, and $c$ used in equation: $f=a$ (residue rate) ${ }^{b} /$ (Reynolds number) ${ }^{c}$ where residue rate is in metric tons per hectare. 
TABLE 6. Regression Equatons for Darey Wabhah Roughness Coeficient versus Residue Rate and Reynolds Number for Reynolds Number Greater than 20,000

\begin{tabular}{|c|c|c|c|c|}
\hline \multirow[b]{2}{*}{$\begin{array}{c}\text { Residue type } \\
\text { (1) }\end{array}$} & \multicolumn{3}{|c|}{ Regression Coefficients $^{\mathrm{a}}$} & \multirow{2}{*}{$\begin{array}{c}\text { Coefficient of } \\
\text { determination; } r^{2} \\
\text { (5) }\end{array}$} \\
\hline & $\begin{array}{c}a \\
(2)\end{array}$ & $\begin{array}{c}b \\
(3)\end{array}$ & $\begin{array}{c}c \\
(4) \\
\end{array}$ & \\
\hline Corn & $1.80 \times 10^{+1}$ & 2.12 & $6.03 \times 10^{-1}$ & 0.908 \\
\hline Cotton & $3.62 \times 10^{-1}$ & 1.31 & $1.39 \times 10^{-1}$ & 0.917 \\
\hline Peanut & 1.75 & $9.51 \times 10^{-1}$ & $2.33 \times 10^{-1}$ & 0.913 \\
\hline Pine needles & 2.20 & 1.20 & $2.89 \times 10^{-1}$ & 0.834 \\
\hline Sorghum & 4.50 & 1.90 & $5.30 \times 10^{-1}$ & 0.812 \\
\hline Soybeans & $6.41 \times 10^{-1}$ & 1.79 & $3.57 \times 10^{-1}$ & 0.768 \\
\hline Sunflower & 2.70 & 1.77 & $4.26 \times 10^{-1}$ & 0.839 \\
\hline Wheat & $3.18 \times 10^{-1}$ & $8.54 \times 10^{-1}$ & $3.35 \times 10^{-2}$ & 0.618 \\
\hline $\begin{array}{l}\text { All residue types } \\
\text { combined }\end{array}$ & 2.84 & 1.06 & $3.01 \times 10^{-1}$ & 0.664 \\
\hline
\end{tabular}

${ }^{a}$ Regression coefficients $a, b$, and $c$ used in equation: $f=a$ (residue rate) ${ }^{b} /$ (Reynolds number) ${ }^{c}$ where residue rate is in metric tons per hectare.

Separate equations for estimating Manning roughness coefficients were developed for Reynolds numbers less than and greater than 20,000. Tables 7 and 8 present equations used for predicting Manning roughness coefficients using percent cover and Reynolds number as independent variables. Using data from all of the residue types, a generalized equation was derived for estimating roughness coefficients for Reynolds numbers less than 20,000 (Table 7).

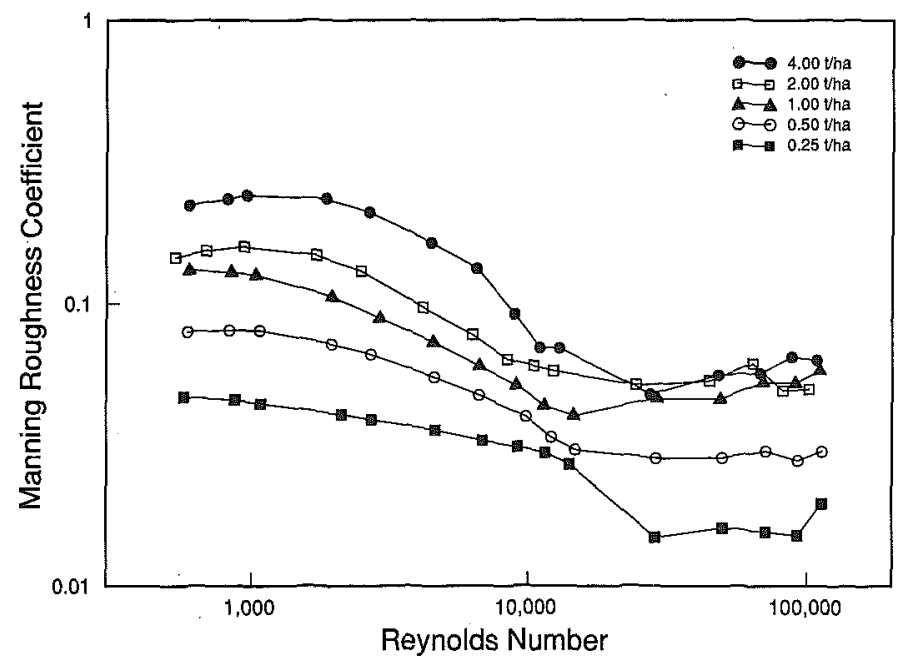

FIG. 2. Manning Roughness Coefficients as Function of Reynolds Number for Selected Rates of Wheat Residue 
TABLE 7. Regrassion Eguations for Manning Roughness Coefficient versus Percent Cover and Reynolds Number for Reynolds Number Less than 20,000

\begin{tabular}{|c|c|c|c|c|}
\hline \multirow[b]{2}{*}{$\begin{array}{c}\text { Residue type } \\
\text { (1) }\end{array}$} & \multicolumn{3}{|c|}{ Pegression Coefficients ${ }^{a}$} & \multirow{2}{*}{$\begin{array}{l}\text { Coefficient of } \\
\text { determination, } r^{2} \\
(5)\end{array}$} \\
\hline & $\begin{array}{c}a \\
(2)\end{array}$ & $\begin{array}{c}b \\
(3)\end{array}$ & $\begin{array}{c}c \\
(4)\end{array}$ & \\
\hline Corn & $4.96 \times 10^{-3}$ & $8.92 \times 10^{-1}$ & $3.11 \times 10^{-2}$ & 0.898 \\
\hline Cotton & $8.96 \times 10^{-3}$ & $6.78 \times 10^{-1}$ & $9.30 \times 10^{-3}$ & 0.941 \\
\hline Peanut & $2.73 \times 10^{-2}$ & $7.03 \times 10^{-1}$ & $1.91 \times 10^{-1}$ & 0.893 \\
\hline Pine needles & $5.39 \times 10^{-3}$ & 1.04 & $1.92 \times 10^{-1}$ & 0.866 \\
\hline Sorghum & $7.85 \times 10^{-2}$ & $4.88 \times 10^{-1}$ & $1.98 \times 10^{-2}$ & 0.879 \\
\hline Soybeans & $4.51 \times 10^{-2}$ & $9.13 \times 10^{-1}$ & $3.58 \times 10^{-1}$ & 0.771 \\
\hline Sunflower & $4.13 \times 10^{-2}$ & $4.39 \times 10^{-1}$ & $8.93 \times 10^{-2}$ & 0.907 \\
\hline Wheat & $2.07 \times 10^{-3}$ & 1.46 & $3.02 \times 10^{-1}$ & 0.899 \\
\hline All residue types & & & & \\
\hline combined & $1.89 \times 10^{-2}$ & $7.12 \times 10^{-1}$ & $1.42 \times 10^{-1}$ & 0.576 \\
\hline
\end{tabular}

${ }^{a}$ Regression coefficients $a, b$, and $c$ used in equation: $n=a$ (percent cover) ${ }^{b} /$ (Reynolds number) ${ }^{c}$.

As can be seen in Fig. 2, very little change in Manning roughness coefficients occurred for Reynolds number values greater than 20,000. For some of the residue materials, a small increase in hydraulic resistance occurred with increasing Reynolds number for Reynolds numbers above 20,000 . This is further demonstrated by the negative $c$ coefficients shown for selected residue materials in Table 8 . The phenomenon of greater roughness coefficient with increasing Reynolds number for very rough surfaces was discussed by Morris (1963).

Manning roughness coefficients can be estimated from values of residue rate for Reynolds numbers less than and greater than 20,000 using Tables 9 and 10, respectively. Again, as evidenced by the negative $c$ coefficients in Table 10, small increases in roughness coefficients as Reynolds number became larger were found for some residue materials at Reynolds numbers

TABLE 8. Regression Equations for Manning Roughness Coefficient versus Percent Cover and Reynolds Number for Reynolds Number Greater than 20,000

\begin{tabular}{l|c|c|c|c}
\hline \multirow{2}{*}{$\begin{array}{c}\text { Residue } \\
\text { type } \\
(1)\end{array}$} & \multicolumn{3}{|c|}{ Regression Coefficients } & \multicolumn{2}{c}{\begin{tabular}{c} 
Coefficient of \\
determination, $r^{2}$ \\
\cline { 2 - 5 }
\end{tabular}} & $\begin{array}{c}a \\
\text { Corn }\end{array}$ & $\begin{array}{c}b \\
(3)\end{array}$ & $\begin{array}{c}c \\
(4)\end{array}$ & $(5)$ \\
\hline Cotton & $5.19 \times 10^{-3}$ & 1.20 & $1.77 \times 10^{-1}$ & 0.846 \\
Peanut & $4.73 \times 10^{-3}$ & $7.00 \times 10^{-1}$ & $-3.26 \times 10^{-2}$ & 0.877 \\
Pine needles & $7.73 \times 10^{-3}$ & $4.11 \times 10^{-1}$ & $-5.09 \times 10^{-2}$ & 0.861 \\
Sorghum & $3.32 \times 10^{-4}$ & 1.23 & $3.11 \times 10^{-3}$ & 0.835 \\
Soybeans & $2.63 \times 10^{-2}$ & $7.14 \times 10^{-1}$ & $1.89 \times 10^{-1}$ & 0.815 \\
Sunflower & $1.59 \times 10^{-3}$ & $9.61 \times 10^{-1}$ & $5.10 \times 10^{-2}$ & 0.772 \\
Wheat & $4.11 \times 10^{-3}$ & $8.58 \times 10^{-1}$ & $3.30 \times 10^{-2}$ & 0.832 \\
\hline
\end{tabular}

${ }^{a}$ Regression coefficients $a, b$, and $c$ used in equation: $n=a$ (percent cover) ${ }^{b} /($ Reynolds number) ${ }^{c}$. 
TABLE 9. Fegression Equaton for Mamning Dorghnes: Cosficient versus Residue Rate and Reynolds Number for Reynolds Number Less than 20,000

\begin{tabular}{|c|c|c|c|c|}
\hline \multirow{2}{*}{$\begin{array}{c}\text { Residue } \\
\text { type } \\
\text { (1) }\end{array}$} & \multicolumn{3}{|c|}{ Regression Coefficients ${ }^{a}$} & \multirow{2}{*}{$\begin{array}{l}\text { Coefficient of } \\
\text { determination, } r^{2} \\
\text { (5) }\end{array}$} \\
\hline & $\begin{array}{c}a \\
(2)\end{array}$ & $\begin{array}{c}b \\
(3)\end{array}$ & $\begin{array}{c}c \\
(4)\end{array}$ & \\
\hline Corn & $5.18 \times 10^{-2}$ & $6.61 \times 10^{-1}$ & $2.37 \times 10^{-2}$ & 0.865 \\
\hline Cotton & $3.00 \times 10^{-2}$ & $6.26 \times 10^{-1}$ & $8.02 \times 10^{-3}$ & 0.958 \\
\hline Peanut & $1.21 \times 10^{-1}$ & $6.83 \times 10^{-1}$ & $1.77 \times 10^{-1}$ & 0.916 \\
\hline Pine needles & $2.00 \times 10^{-1}$ & $5.02 \times 10^{-1}$ & $1.83 \times 10^{-1}$ & 0.867 \\
\hline Sorghum & $2.60 \times 10^{-1}$ & $4.22 \times 10^{-1}$ & $1.98 \times 10^{-1}$ & 0.869 \\
\hline Soybeans & $7.25 \times 10^{-1}$ & $5.97 \times 10^{-1}$ & $3.59 \times 10^{-1}$ & 0.771 \\
\hline Sunflower & $1.24 \times 10^{-1}$ & $3.60 \times 10^{-1}$ & $1.02 \times 10^{-1}$ & 0.902 \\
\hline Wheat & 1.13 & $4.96 \times 10^{-1}$ & $3.36 \times 10^{-1}$ & 0.942 \\
\hline
\end{tabular}

"Regression coefficients $a, b$, and $c$ used in equation: $n=a(\text { residue rate })^{b} /($ Reynolds number $)^{c}$ where residue rate is in metric tons per hectare.

above 20,000 . For Reynolds numbers greater than 20,000 , a generalized equation was obtained for estimating Manning roughness coefficients (Table $10)$.

\section{Use of Regression Equations}

If roughness coefficients are required for other vegetative materials, the residue type used in this study most similar to the material under consideration should be identified. Estimates of resistance factors can then be made using the previously identified equations. The generalized relationships can also be used to predict roughness coefficients for other vegetative materials. When using the generalized relationships, the physical characteristics of the material under consideration should be similar to those used in this investigation (Table 1).

TABLE 10. Regression Equations for Manning Roughness Coefficient versus Residue Rate and Reynolds Number for Reynolds Number Greater than 20,000

\begin{tabular}{|c|c|c|c|c|}
\hline \multirow[b]{2}{*}{$\begin{array}{c}\text { Residue type } \\
\text { (1) }\end{array}$} & \multicolumn{3}{|c|}{ Regression Coefficients $^{a}$} & \multirow{2}{*}{$\begin{array}{c}\text { Coefficient of } \\
\text { determination, } r^{2} \\
(5)\end{array}$} \\
\hline & $\begin{array}{c}a \\
(2)\end{array}$ & $\begin{array}{c}b \\
(3)\end{array}$ & $\begin{array}{c}c \\
(4)\end{array}$ & \\
\hline Corn & $1.21 \times 10^{-1}$ & $9.27 \times 10^{-1}$ & $1.74 \times 10^{-1}$ & 0.875 \\
\hline Cotton & $1.61 \times 10^{-2}$ & $6.61 \times 10^{-1}$ & $-3.35 \times 10^{-2}$ & 0.902 \\
\hline Peanut & $2.93 \times 10^{-2}$ & $4.87 \times 10^{-1}$ & $-2.88 \times 10^{-3}$ & 0.904 \\
\hline Pine needles & $5.30 \times 10^{-2}$ & $5.72 \times 10^{-1}$ & $6.27 \times 10^{-2}$ & 0.845 \\
\hline Sorghum & $1.36 \times 10^{-1}$ & $6.81 \times 10^{-1}$ & $1.90 \times 10^{-1}$ & 0.792 \\
\hline Soybeans & $3.00 \times 10^{-2}$ & $5.92 \times 10^{-1}$ & $4.55 \times 10^{-2}$ & 0.773 \\
\hline Sunflower & $6.67 \times 10^{-2}$ & $7.37 \times 10^{-1}$ & $1.17 \times 10^{-1}$ & 0.828 \\
\hline Wheat & $3.37 \times 10^{-2}$ & $4.57 \times 10^{-1}$ & $-3.18 \times 10^{-3}$ & 0.875 \\
\hline $\begin{array}{l}\text { All residue types } \\
\text { combined }\end{array}$ & $5.23 \times 10^{-2}$ & $5.73 \times 10^{-1}$ & $6.44 \times 10^{-2}$ & 0.590 \\
\hline
\end{tabular}

${ }^{\mathrm{a}}$ Regression coefficients $a, b$, and $c$ used in equation: $n \stackrel{!}{=} a\left(\right.$ residue rate) ${ }^{b} /$ (Reynolds number) ${ }^{c}$ where residue rate is in metric tons per hectare. 
Residue materials used in this study were glued in place during the experimental tests. Under natural conditions, the residue materials may move at higher flow rates causing substantial changes in flow resistance. At present, the shear stress required to initiate movement of residue materials is not well defined.

\section{Summary AND Conclusions}

Analysis of surface runoff on upland areas requires identification of hydraulic roughness coefficients. Total hydraulic resistance at a site may be a composite of roughness components caused by several factors. In this investigation, roughness coefficients were identified for selected residue materials.

Experimental variables used in this study included residue type, residue rate, and flow rate. Selected rates of corn, cotton, peanut, pine needles, sorghum, soybeans, sunflower, and wheat residue were glued in a random orientation on sections of reinforced fiberglass sheeting. Measurements of residue surface cover were made, and the fiberglass sheets were placed in a flume. Steady uniform flow conditions were then established for a wide range of discharge rates.

Darcy-Weisbach and Manning roughness coefficients were calculated from measurements of discharge rate and flow velocity. Regression relationships were developed, which related the roughness coefficients to Reynolds number and either percent residue cover or residue rate. Both surface cover and residue rate are frequently used to describe the amount of vegetative material found on a soil surface. Generalized equations for predicting roughness coefficients for other types of residue material are also presented.

Several factors may contribute to hydraulic resistance on upland areas. Information is needed on roughness coefficients provided by each of these factors, their contribution to total hydraulic roughness, and the effect of flow rate on roughness coefficients. This information will improve our ability to understand and accurately model upland flow hydraulics.

\section{ACKNOWLEDGMENT}

This paper is a contribution from USDA-ARS, in cooperation with the Agricultural Research Division, University of Nebraska, Lincoln, and is published as Journal Series No. 9309.

\section{Appendix I. References}

Abrahams, A. D., Parsons, A. J., Luk, S. H. (1986). "Resistance to overland flow on desert hillslopes." J. Hydro., 88, 343-363.

Chow, V. T. (1959). Open channel hydraulics. McGraw Hill, New York, N.Y.

Colvin, T. S., Berry, E. C., Erbach, D. C., and Laflen, J. M. (1986). "Tillage implement effects on corn and soybean residue." Trans. Am. Soc. Agric. Engrs., American Society of Agricultural Engineers, 29(1), 56-59.

Dunne, T., and Dietrich, W. E. (1980). "Experimental study of Horton overland flow on tropical hillslopes. 2. Hydraulic characteristics and hillslope hydrographs." Z. Geomphol. Suppl. Band., 35, 60-80.

Emmett, W. W. (1970). "The hydraulics of overland flow on hillslopes." U.S. Geological Survey Prof. Paper 662-A, U.S. Govt. Printing Office, Washington, D.C. 
Engman, E. T. (1986). "Roughness coefficients for routing surface runoff." J. Irrig. Drain. Engrg., ASCE, 112(1), 39-53.

Gilley, J. E., Kottwitz, E. R., and Simanton, J. R. (1990). "Hydraulic characteristics of rills." Trans. Am. Soc. Agric. Engrs., American Society of Agricultural Engineers, 33(6), 1900-1906.

Laflen, J. M., Baker, J. L., Hartwig, R. O., Buchele, W. F., and Johnson, H. P. (1978). "Soil and water loss from continuous row cropping." Trans. Am. Soc. Agric. Engrs., American Society of Agricultural Engineers, 21(5), 881-885.

Liong, S. Y., Selvalingam, S., and Brady, D. K. (1989). "Roughness values for overland flow in subcatchments." J. Irrig. Drain. Engrg., ASCE, 115(2), 203214.

Morris, H. M. (1963). Applied hydraulics in engineering. Ronald Press, New York, N.Y.

Phelps, H. O. (1975). "Shallow laminar flows over rough granular surfaces." $J$. Hydr. Div., ASCE, 101(3), 367-384.

Roels, J. M. (1984). "Flow resistance in concentrated overland flow on rough slope surfaces." Earth Surface Processes and Landforms, 9, 541-551.

Savat, J. (1980). "Resistance to flow in rough supercritical sheet flow." Earth Surface Processes and Landforms, 5, 103-122.

Shen, W. S., and Li, R. H. (1973). "Rainfall effect on sheet flow over smooth surface." J. Hydr. Div., ASCE, 99(5), 771-792.

Woo, D. C., and Brater, E. F. (1961). "Laminar flow in rough rectangular channels." J. Geophys. Res., 66(12), 4207-4217.

\section{ApPEndix II. NOTATION}

The following symbols are used in this paper:

$A=$ cross-sectional flow area;

$b=$ flow width;

$f=$ Darcy-Weisbach roughness coefficient;

$g=$ acceleration due to gravity;

$n=$ Manning roughness coefficient;

$P=$ wetted perimeter;

$Q=$ flow rate;

$R=$ hydraulic radius;

$\mathrm{R}=$ Reynolds number;

$S=$ average slope;

$V=$ flow velocity;

$y=$ flow depth; and

$v=$ kinematic viscosity. 